\title{
Host genetics of invasive Aspergillus and Candida infections
}

\author{
Agnieszka Wójtowicz • Pierre-Yves Bochud
}

Received: 7 October 2014 / Accepted: 6 November 2014 / Published online: 18 November 2014

(C) Springer-Verlag Berlin Heidelberg 2014

\begin{abstract}
Invasive candidiasis and aspergillosis are major complications in surgical and onco-hematological patients, and still associated with an important morbidity and mortality. A large number of studies highlighted the potential role of host genetic polymorphisms that may influence susceptibility to fungal pathogens, but many were limited by insufficient statistical power, problematic design, and/or lack of replication. However, some relevant polymorphisms are now emerging from well-conducted studies whose associations have been replicated and/or are supported by strong biological evidence. Such polymorphisms together with other biomarkers may play a role in the prediction, diagnosis, and management of severe fungal infections in high-risk patients in the coming years.
\end{abstract}

Keywords Innate immunity · Single-nucleotide polymorphism · Genetic susceptibility $\cdot$ Invasive Candida infection · Invasive aspergillosis

\section{Invasive fungal infections}

Candida and Aspergillus are the two most common causes of invasive fungal infections [1,2]. Candida species are among the top 10 bloodstream pathogens among hospitalized patients, with an incidence of $\sim 0.5$ cases per 10,000 patient days $[1,3]$. Non-candidemic forms of the infection include intraabdominal candidiasis in patients with complicated

This article is a contribution to the special issue on Immunopathology of Fungal Diseases - Guest Editor: Jean-Paul Latge

A. Wójtowicz $\cdot$ P.-Y. Bochud $(\bowtie)$

Infectious Disease Service, Department of Medicine, Lausanne

University Hospital (CHUV), Rue du Bugnon 46, 1011 Lausanne,

Switzerland

e-mail: pierre-yves.bochud@chuv.ch gastrointestinal tract surgery [4-6] and hepatosplenic candidiasis in hematological patients with prolonged neutropenia and severe gastrointestinal tract mucositis [7]. Invasive aspergillosis (IA) occurs almost exclusively in immunocompromised patients, including those with hematological malignancies and/or hematopoietic stem cell transplant (HSCT) recipients (incidence $3-5 \%[2,8]$ ) or solid organ transplant (SOT) recipients (incidence 1-3\% [2, 9, 10,]). Despite recent improvement in the prevention, diagnosis, and management of these infections, the mortality associated with both invasive candidiasis and aspergillosis still ranges 30-60\% [2, 3, 11-13].

The development of severe bacterial and fungal infections can be associated with several risk factors, including patient age, comorbid conditions, and/or immunosuppressive drugs [5]. Yet, it is still difficult to predict why certain individuals develop severe infections, while others, under similar conditions, do not. Since the prognosis of invasive fungal infections is severe, prophylactic and empirical anti-fungal agents are increasingly used, exposing patients to the potential development of resistance and/or unnecessary side effects. Therefore, better risk stratification may improve the use anti-fungal drugs. Over the last years, an increasing number of studies were analyzed whether genetic polymorphisms influence susceptibility to or severity of invasive fungal infections. Most studies so far used a candidate gene approach strategy, focused on one or several genes selected for their role in immune responses against fungal pathogen.

\section{Immune responses to fungal infections}

The innate immune system is composed of physical barriers (skin and mucous membranes), cellular elements (monocytes, macrophages, neutrophils, dendritic cells (DCs), mast cells, natural killer (NK) cells), and soluble factors (cytokines, 
chemokines, and others), which all contribute to contain the spread of infection. The interaction of fungal pathogens with innate immune cells triggers subsequent adaptive immune mechanisms, including $\mathrm{T}$ cell responses and $\mathrm{B}$ cell differentiation [14].

At the molecular level, detection of fungal pathogens by innate immune cells is mediated by a series of pattern recognition receptors (PRRs). PRRs detect specific molecular patterns from microorganisms as well as biological components of the self, jointly called "pathogen- or danger-associated molecular patterns" (PAMPs or DAMPs), and mediate subsequent responses through the activation of their downstream signaling pathways. At least three families of PRRs have been shown to be involved in fungal detection, including the Toll-like receptors (TLRs), the C-type lectin receptors (CLRs, such as Dectin1, Dectin-2, DC-specific ICAM3 grabbing non-integrin (DCSIGN)), and NOD-like receptors (NLRs such as NLR family) pyrin domain containing 3 (NALP3, reviewed in $[15,16]$ ). Among TLRs, fungal recognition is mediated by TLR4 $(O-$ linked mannan [17]) and TLR2 (phospholipomannan [18]), a receptor that forms heterodimers with either TLR1 or TLR6. Among CLRs, Dectin-1 was shown to detect $\beta$-glucan ( $\beta$-(1,3)-D-glucan), a key component of Candida and Aspergillus cell wall [19-21]. The role NLRs in immunity to fungal pathogens has been recently suggested by in vitro and in vivo studies. In human monocytes, NALP3 was shown to be involved in response to Aspergillus hyphae by Dectin-1dependent inflammasome formation leading to interleukin-1 beta (IL-1 $\beta$ ) cleavage and release [22]. Sensing diverse fungal components Dectin-1, TLRs, and NLRs mediates responses in a quite distinct way; nevertheless, they can act synergistically to enhance immune reaction [23, 24]. In addition, pentraxin-3 (PTX3) was shown to be an important soluble PRR of fungal pathogens [25]. It has been shown to bind and opsonize Aspergillus conidia by recognizing galactomannan, thereby facilitating pathogen recognition, increasing phagocytosis, and killing of this offending pathogen [25].

PRRs located on the surface of antigen-presenting cells activate transcription factors through different signaling pathways, thereby inducing the production of pro- and antiinflammatory molecules, which play a central role in immune responses to fungal pathogens. The pattern of cytokines and other mediators in response to fungal pathogens determines the differentiation of CD4+ T helper cells [15]. $\mathrm{T}_{\mathrm{H}} 1$ responses characterized mainly by the production of interferon gamma (IFN- $\gamma$ ) are usually associated with protective immunity against fungal pathogens $[15,26]$. The activations of $\mathrm{T}_{\mathrm{H}} 17$ cells characterized by the production of IL-17 and IL-22 were shown to ensure mucosal immunity against Candida albicans infection [15, 27]. The anti-fungal immune responses can be counterbalanced by the differentiation of $\mathrm{T}$ helper cells into $\mathrm{T}_{\mathrm{H}} 2$ (IL-4) and Treg cells (IL-10), which can be associated with insufficient responses against fungal pathogens.

\section{Immunogenetics of fungal infections}

Over the last decades, increasing evidence highlighted the importance of host genetic factors in susceptibility to human pathogens, including opportunistic and non-invasive fungi [28]. Predisposition to infections is usually considered to segregate into two groups [29]. On the one hand, individuals with primary immunodeficiencies usually present with infections due to common or opportunistic pathogens, resulting from a clear-cut deficit in a single gene (monogenic inheritance). Such immune deficiencies are usually limited to a very small number of individuals or families, but the identification of genetic defects is very informative on immune defense mechanisms. On the other hand, susceptibility to infections in the general population can be influenced by polymorphisms in several genes (polygenic inheritance) [30]. Although the identification of such polymorphisms may be relevant to implement personalized management strategies in certain circumstances (for example, during chemotherapy-induced neutropenia), their specific contribution to the phenotype is often more difficult to establish.

Monogenic inheritance Several well-characterized primary immunodeficiencies can predispose to IA (Table 1). Increased susceptibility to the infection either an insufficient number of phagocytic cells (severe congenital neutropenia $(\mathrm{SCN})$ with mutation in HCLS1-associated protein X-1 or neutrophil elastase $[31,32])$, inability for granulocytes to reach the site of infection (leukocyte adhesion deficiency type 1 with autosomal recessive deficiency in CD18 [33]), or impaired phagocytic functions (mainly due to inability to produce reactive oxygen species (ROS) such as in chronic granulomatous disease (reviewed in [34-37]). IA can also occur in patients with hyperimmunoglobulin E syndrome (HIES) characterized by autosomal-dominant STAT3 deficiency and epithelial lung dysfunction [38, 39] and those with sporadic monocytopenia and mycobacterial infection (MonoMAC) syndrome with DC deficiency and B and NK cell lymphopenia $[40,41]$. Some of primary immunodeficiencies associated with IA have been also reported to cause invasive forms of Candida infections [42, 43, 32, 31, 33]. Yet, several other types of primary immunodeficiencies are a cause of chronic mucocutaneous candidiasis (CMC), a noninvasive form of candidiasis characterized by persistent or recurrent fungal infection of the skin, oral or genital mucous, and nails. Those are usually classified into three groups: $\mathrm{CMC}$ associated with primary $\mathrm{T}$ cell deficiency, syndromic $\mathrm{CMC}$ defined as $\mathrm{CMC}$ infection associated with presence of other clinical manifestation, and CMC disease (CMCD) defined as CMC infection that occurs without other underlying disease (Table 1). In some instances, deficiencies associated with CMC can also predispose to more invasive infections, such as autosomal-dominant point 
Table 1 Primary immunodeficiencies associated with Candida and Aspergillus infections

\begin{tabular}{|c|c|c|c|}
\hline Gene & Transmission of mutation & Associated disease & Study \\
\hline \multicolumn{4}{|l|}{ Invasive aspergillosis } \\
\hline CYBB & X-linked & Chronic granulomatous disease & $\begin{array}{l}\text { Lionakis, Lilic, Vinh, and } \\
\text { Lanternier et al. [34-37] }\end{array}$ \\
\hline CYBA & Autosomal recessive & Chronic granulomatous disease & $\begin{array}{l}\text { Lionakis, Lilic, Vinh, and } \\
\text { Lanternier et al. [34-37] }\end{array}$ \\
\hline NCF1, NCF2, NCF4 & Autosomal recessive & Chronic granulomatous disease & $\begin{array}{l}\text { Lionakis, Lilic, Vinh, and } \\
\text { Lanternier et al. [34-37] }\end{array}$ \\
\hline STAT3 & Autosomal-dominant & Hyperimmunoglobulin E syndrome & $\begin{array}{l}\text { Holland et al. and Minegishi } \\
\text { et al. }[38,39]\end{array}$ \\
\hline GATA2 & Autosomal-dominant & $\begin{array}{l}\text { Sporadic monocytopenia and } \\
\text { mycobacterial infection }\end{array}$ & $\begin{array}{c}\text { Camargo et al., Vinh et al., and } \\
\text { Glocker et al. [40, 41, 85] }\end{array}$ \\
\hline HAX1 & Autosomal recessive & Severe congenital neutropenia & Klein et al. [32] \\
\hline ELA2 & Autosomal-dominant & Severe congenital neutropenia & Dale et al. [31] \\
\hline $\mathrm{CD} 18$ & Autosomal recessive & Leukocyte adhesion deficiency type 1 & Fischer et al [33] \\
\hline \multicolumn{4}{|c|}{$\mathrm{CMC}$ associated with $\mathrm{T}$ cell deficiency } \\
\hline DOCK8 & Autosomal recessive & Combined immunodeficiencies & Zhang et al. [86] \\
\hline IKBG & $\mathrm{X}$-linked recessive & Combined immunodeficiencies & Picard et al. [87] \\
\hline IKBA & Autosomal-dominant, GOF & Combined immunodeficiencies & Schimke et al. [88] \\
\hline TCRA & Autosomal recessive & Combined immunodeficiencies & Morgan et al. [89] \\
\hline CRACM1 & Autosomal recessive & Combined immunodeficiencies & Feske et al. [90] \\
\hline MST1/STK4 & Autosomal recessive & Combined immunodeficiencies & $\begin{array}{l}\text { Abdollahpour et al. and } \\
\text { Nehme [91, 92] }\end{array}$ \\
\hline IL2RA & Autosomal recessive & Combined immunodeficiencies & Caudy et al. [93] \\
\hline $\begin{array}{l}\text { CIITA, RFXANK, } \\
\text { RFXC, RFXAP }\end{array}$ & Autosomal recessive & Combined immunodeficiencies & Ouederni et al. [94] \\
\hline UNC119 & Autosomal-dominant & Idiopathic CD4 lymphopenia & Gorska et al. [95] \\
\hline MAGT1 & X-linked & Idiopathic CD4 lymphopenia & Li et al. [96] \\
\hline RAG1 & Autosomal recessive & Idiopathic CD4 lymphopenia & Kuijpers et al. [97] \\
\hline Over 30 genes & $\begin{array}{l}\text { Autosomal recessive or } \\
\text { X-linked }\end{array}$ & Severe combined immunodeficiencies & Puck [98] \\
\hline \multicolumn{4}{|l|}{ Syndromic CMC } \\
\hline STAT3 & Autosomal-dominant & Hyperimmunoglobulin E syndrome & $\begin{array}{l}\text { Holland et al., Minegishi et al., } \\
\text { Chandesris et al., and } \\
\text { Woellner et al. } \\
{[38,39,99,100]}\end{array}$ \\
\hline DOCK8 & Autosomal recessive & Hyperimmunoglobulin E syndrome & Engelhardt et al. [101] \\
\hline AIRE & Autosomal recessive & APECED/APS-I & $\begin{array}{l}\text { Kisand et al. and Sarkadi et al. } \\
{[102,103]}\end{array}$ \\
\hline TYK2 & Autosomal recessive & Hyperimmunoglobulin E syndrome & Minegishi et al. [104] \\
\hline IL12RB1 & Autosomal recessive & IL-12RB1 deficiency, MSMD & de Beaucoudrey et al. [105] \\
\hline IL12B & Autosomal recessive & IL-12p40 deficiency & Prando et al. [106] \\
\hline
\end{tabular}

CMC disease (CMCD) 
Table 1 (continued)

\begin{tabular}{lllc}
\hline Gene & Transmission of mutation & Associated disease & Study \\
\hline CARD9 & Autosomal recessive & CMC & Glocker et al. [85] \\
IL17F & Autosomal-dominant & CMC & Puel et al. [107] \\
IL17RA & Autosomal recessive & CMC & Puel et al. [107] \\
STAT1 & Autosomal-dominant, GOF & CMC & Liu et al. and van de Veerdonk \\
& & & et al. [108, 109] \\
ACT1 & Missense mutation & CMC & Boisson et al. [110] \\
Invasive Candida infections & & & Lanternier et al. and Drewniak \\
CARD9 & Autosomal recessive & Meningoencephalitis & et al. [45, 46] \\
CYBB & & & Levy et al. and Fleischmann et al. \\
& X-linked & Chronic granulomatous disease & [42, 43] \\
CYBA, NCF1, & & & Levy et al. and Fleischmann et al. \\
NCF2, NCF4 & Autosomal recessive & Chronic granulomatous disease & Fischer et al. [33] \\
CD18 & & & Leukocyte adhesion deficiency type 1 \\
ELA2 & Autosomal recessive & Severe congenital neutropenia & Dale et al. [31] \\
HAX1 & Autosomal-dominant & Severe congenital neutropenia & Klein et al. [32]
\end{tabular}

$A C T 1$ nuclear factor-NF-kB activator 1, AIRE autoimmune regulator, APECED/APS-I autoimmune polyendocrinopathy candidiasis ectodermal dystrophy /autoimmune polyendocrinopathy syndrome type I, CARD9 caspase recruitment domain family member 9, $C M C$ chronic mucocutaneous candidiasis, $C R A C M 1 \mathrm{Ca}^{2+}$ channel protein 1, CYBB cytochrome B-245 beta polypeptide, CYBA cytochrome B-245 alpha polypeptide, CIITA class II, major histocompatibility complex transactivator, $D O C K 8$ dedicator of cytokinesis 8, ELA2 elastase 2, GATA2 GATA-binding protein 2, GOF gain of function, $H A X 1$ HCLS1 associated protein X-1, IKBG inhibitor of nuclear factor-kB kinase subunit gamma, $I L$ interleukin, $M A G T 1$ magnesium transporter 1, MSMD mendelian susceptibility to mycobacterial diseases, MST1 mammalian STE20-like kinase, $N C F$ neutrophil cytosolic factor, $R A G 1$ recombination activating gene $1, R F X A N K$ regulatory factor $\mathrm{X}$-associated ankyrin-containing protein, $R F X A P$ regulatory factor $\mathrm{X}$-associated protein, STAT signal transducer and activator of transcription, STK4 serine/threonine kinase 4, TCRA T cell receptor alpha, TYK tyrosine kinase 2, UNC119 unc119 homolog

mutations in interleukin-12 receptor beta 1 (IL12RB1) [44] or inborn deficiency in CARD9 $[45,46]$.

Polygenic inheritance Several studies investigated the role of genetic factors in patients at risk to develop invasive fungal infections, such those with hematological malignancies, HSCT recipients with prolonged neutropenia, or ICU surgical patients (Fig. 1, Tables 2 and 3).

Invasive aspergillosis

Pattern recognition receptors Two non-synonymous polymorphisms in TLR4 (1063A/G (D299G) and 1363C/T (T399I)) in HSCT donors were associated with the risk of IA in the corresponding recipient [47]. This association has been further validated in two independent cohorts of HSCT $[48,47]$; however, other studies showed contradictory results in diverse setting $[49,50]$. The polymorphisms were initially suggested to impair the detection of LPS (TLR4 primary ligand [51]), but the exact mechanism by which it influences immune responses to the fungus has been debated [52]. Polymorphisms in other TLRs (TLR1/TLR6 [49], TLR3 [53], and TLR5 [54]) have also been associated with susceptibility to IA. Although some of these single-nucleotide polymorphisms (SNPs) were shown to influence immune responses to Aspergillus species in vitro [55, 54], the genetic associations have not been replicated so far (Table 2). SNPs in TLR2 (which acts as co-receptor with TLR1 or TLR6) were not associated with susceptibility to IA [50, 47].

A stop codon polymorphism in Dectin-1 (known as CLEC7A) in HSCT donor and/or recipient was associated with IA in the recipient $[56,57]$. Peripheral blood mononuclear cells (PBMCs) from individuals carrying the 238X risk allele produced lower amounts of IL-1 $\beta$, IL-6, IL-17A, and IFN- $\gamma$ and IL-10 compared to PBMCs in response to Aspergillus fumigatus stimulation [56]. Donor and recipient Dectin1 deficiency also increases susceptibility to Aspergillus infection in a mice model of HSCT [56]. These data illustrate the important role of Dectin-1 in immune responses against Aspergillus infection. Two other polymorphisms in CLEC7A have been associated with IA among patients with 


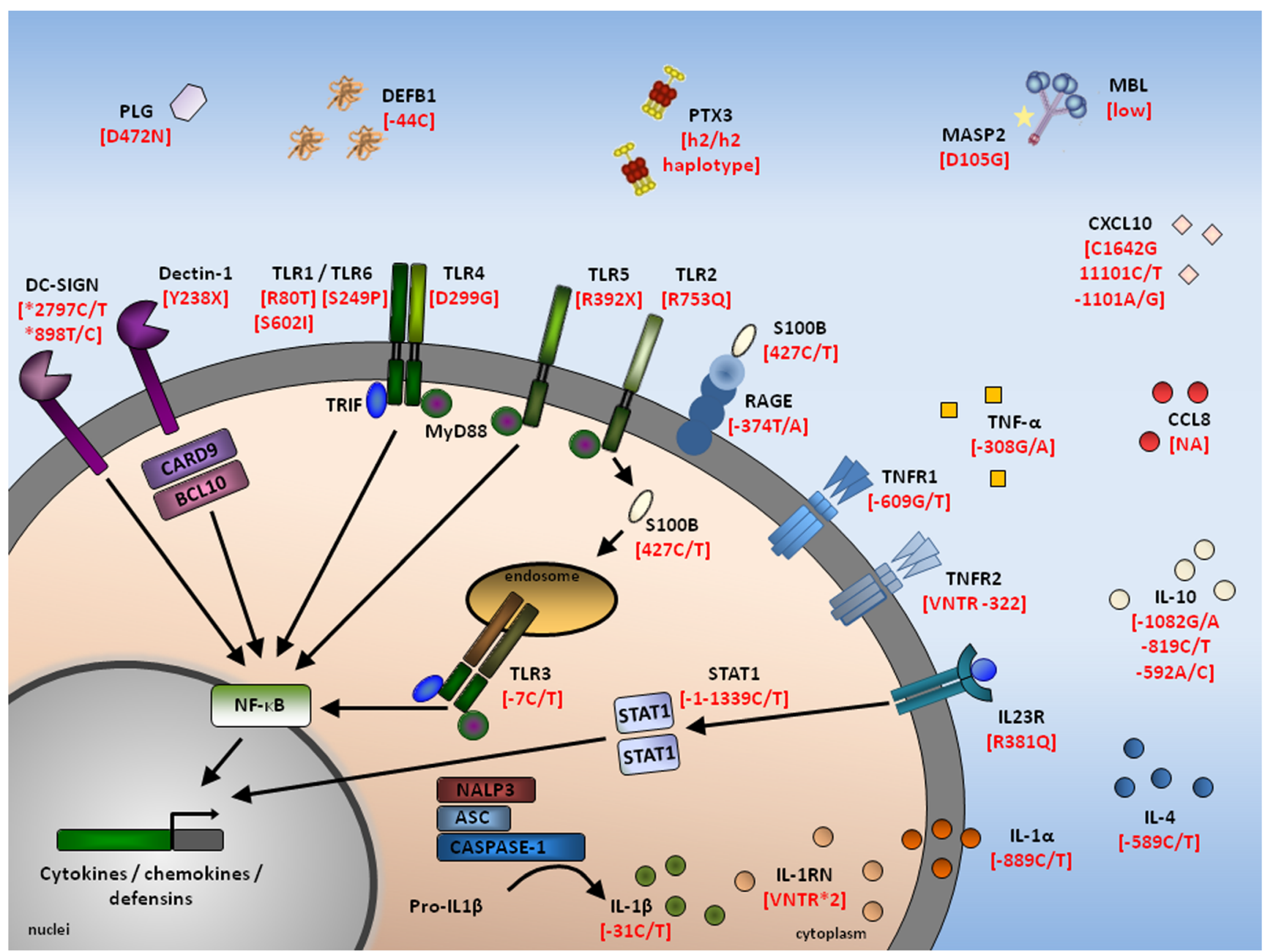

Fig. 1 Candidate gene polymorphisms associated with invasive Aspergillus and/or Candida infections. ASC apoptosis-associated specklike protein containing a CARD; $B C L 10 \mathrm{~B}$ cell CLL/lymphoma 10; $C A R D 9$ caspase recruitment domain-9; CCL8 chemokine C-C motif ligand 8; CXCL10 CXC chemokine ligand-10; DC-SIGN dendritic cellspecific intercellular adhesion molecule-3-grabbing non-integrin; $D E F B 1$ $\beta$-defensin 1; IL interleukin; ILIRN interleukin-1 receptor antagonist; $I L 23 R$ interleukin 23 receptor; MASP2 mannan-binding lectin serine peptidase 2; MBL mannose-binding lectin; MYD88 myeloid differentiation primary response protein; NALP3 NACHT, LRR, and PYD domains-containing protein $3 ; N F-\kappa B$ nuclear factor-kB; $P L G$ plasminogen; $P T X 3$ pentraxin 3; RAGE advanced glycosylation endproduct-specific receptor; $S 100 B$ S100 calcium-binding protein B; STAT1 signal transducer and activator of transcription 1; TNFA tumor necrosis factor alpha; TNFR tumor necrosis factor receptor; TRIF TIRdomain-containing adapter-inducing interferon- $\beta$; TLR Toll-like receptor hematological malignancies. SNPs in another C-type lectin CD290 (encoding DC-SIGN) have been associated with IA in patients with hematological malignancies [58]. The latest studies have not yet been validated, and the functional relevance of the polymorphisms still needs to be further explored.

In a recent study, a haplotypic variant in PTX3 in HSCT donor was associated with an increased risk of IA in the corresponding recipient [59]. This association has been replicated in a cohort of SOT recipients [60]. The variant has been associated with reduced PTX3 expression or production (either in PBMCs or in broncho-alveolar lavage (BAL) from infected or non-infected patients) as well as reduced phagocytic activity in PBMCs. Furthermore, mice deficient in $P T X 3$ have increased susceptibility to IA with defective recognition of Aspergillus conidia compared to WT mice [25]. A haplotype determined by three SNPs in the mannose-binding lectin $(M B L)$, a complement-related PRR playing an important role in opsonization and lysis of fungal pathogens, has been associated with IA [61]. Presence of this haplotype results in low levels of MBL with impaired activity, which could, in part, be responsible for increased susceptibility to invasive infection caused by Aspergillus.

Cytokines, chemokines, and their receptors A series of relatively small studies associated SNPs in genes encoding cytokines and chemokines such as IL10 [62], IL1B [63], IL1A [63], 


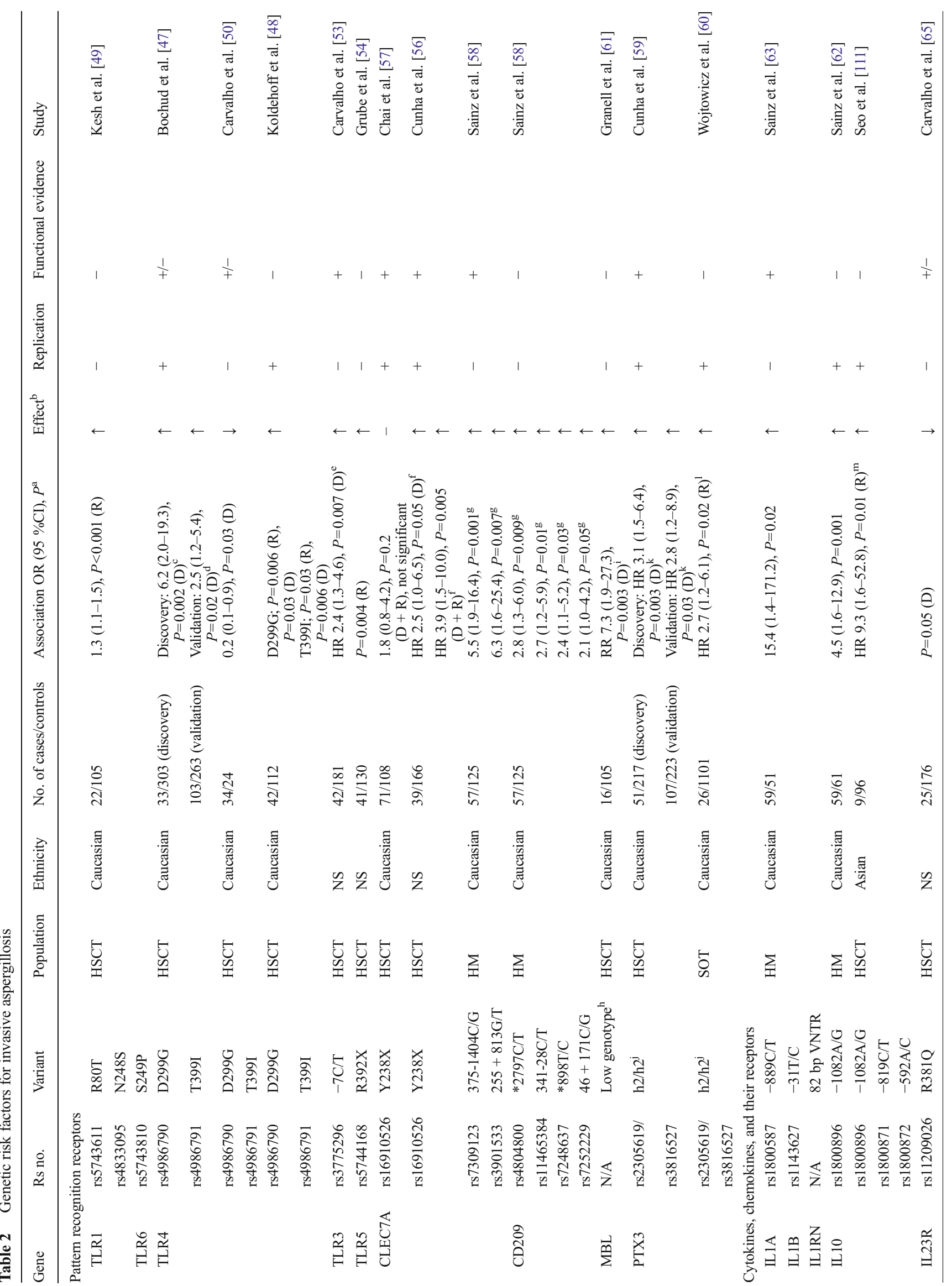




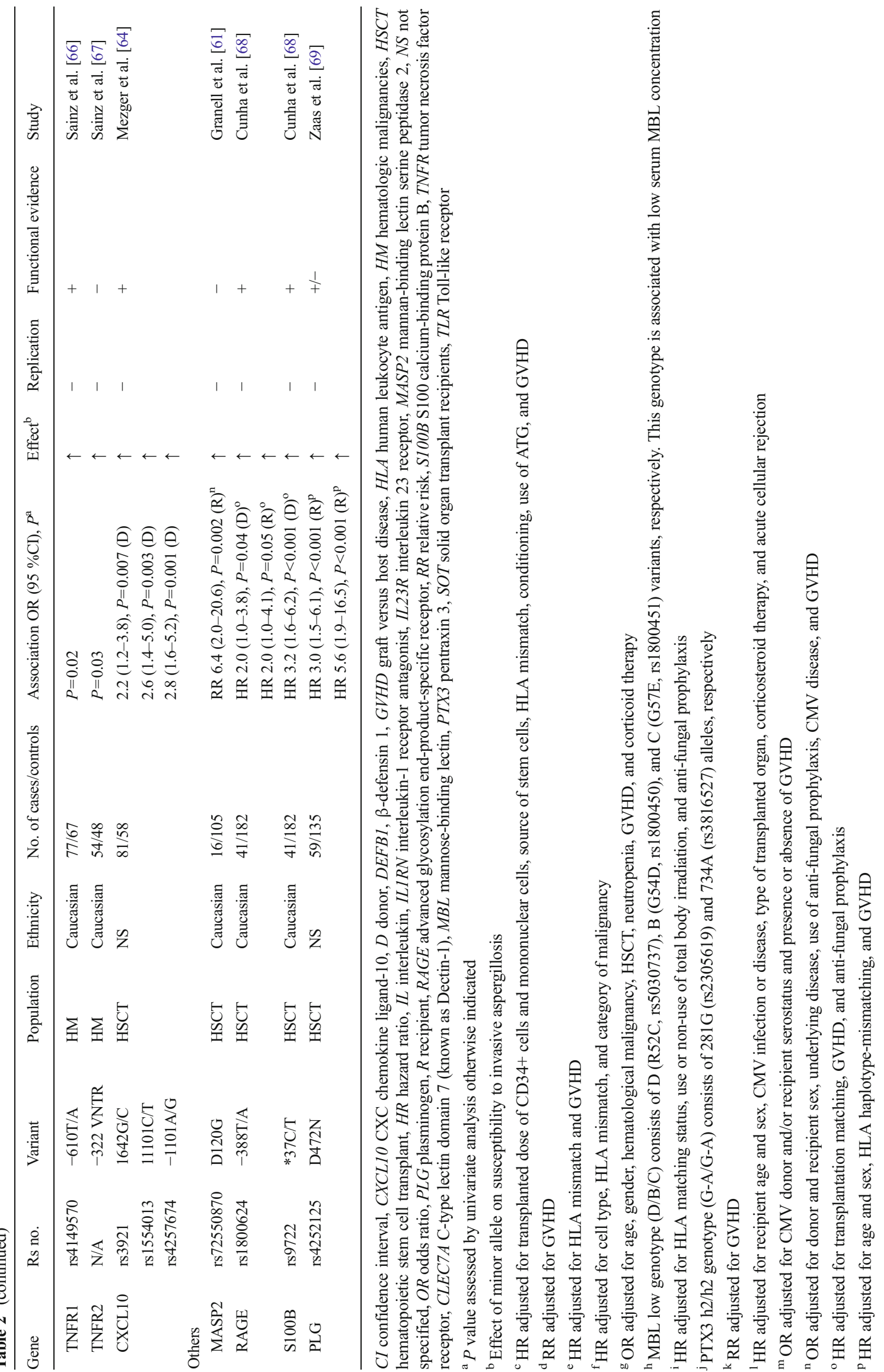


and CXCL10 [64], as well as their receptors (IL23R [65], TNFR1, and TNFR2 $[66,67]$ ) or antagonists (interleukin-1 receptor antagonist, ILIRA [63]) with susceptibility to IA. Among them, only the association with $I L 10$ has been validated by independent researchers, yet without biological clarification (Table 2).

Other genes Other investigators pointed out the role of SNPs located in different genes from signaling pathways involved in immune responses to fungi such as mannan-binding lectin serine peptidase 2 (MASP2) [61], advanced glycosylation end-product receptor $(R A G E)$, alarmin $\mathrm{S} 100$ calcium-binding protein B $(S 100 B)$ [68], and plasminogen (PLG) [69]. However, most of aforementioned studies were without further validation and/or clear functional relevance, thus require further exploration (Table 2).

\section{Invasive Candida infections}

Pattern recognition receptors There is also evidence that dysfunction in main PRR sensing fungal cell wall components is associated with susceptibility to invasive Candida infections. The TLR4 D299G and T399I polymorphisms have been associated with candidemia in non-neutropenic patients [70], but this observation was not confirmed in a larger cohort [71]. However, the same SNPs were associated with Candida colonization in surgical intensive care unit (ICU) patients, although there was no association with the development of intra-abdominal candidiasis [72]. Again, differences between the studies can be explained by the variation in sample size that was not powerful enough for replication. Nonetheless, TLR4-deficient mice have an increased susceptibility to disseminated candidiasis compared to wild-type mice [73]. Three SNPs in TLR1 (R80T, N248S, and S602I) were associated with candidemia [71] and influenced the production of proinflammatory cytokines in PBMCs from affected individuals after stimulation of TLR1/TLR2 agonists [71]. The R753Q polymorphisms in TLR2 have been associated with increased risk for septic candidemia in a very small cohort of ICU patients and correlated with diminished IFN- $\gamma$ and IL- 8 plasma levels in patients carrying two copies of mutant allele [74]. However, larger confirmatory cohort would be desired to confirm this association.

Several studies suggest a role for the Dectin-1 Y238X polymorphism in susceptibility to Candida infections. The SNP was associated with increased Candida colonization in a cohort of HSCT patients [75], but no association could be detected in a casecontrol study of candidemic patients [76]. This may be due to study limitations, such as the heterogeneity among cases and/or controls and/or insufficient power due to the rare SNP allele frequency. Yet, PBMCs from individuals carrying the SNP produced reduced amounts of pro-inflammatory cytokines (TNF- $\alpha$, IL-17) compared to those from WT individuals, after stimulation with Candida spp. [75, 76]. Dectin-1 deficiency inconsistently led to increased susceptibility to infection in mice models of Candida infection [21, 77]. Besides TLRs and CLRs, polymorphisms in the soluble PRR MBL (i.e., "low MBL haplotypes") were also associated with abdominal candidiasis [78].

Cytokines, chemokines, and their receptors Several investigators pointed out the role of SNPs located in key cytokines genes, including TNFA [72], IL12B [79], IL10 [79], and IL4 [80], in the susceptibility to Candida infections or colonization (Table 3). However, most of this studies were limited by several factors, thus need further validation in larger datasets.

Other genes A SNP in $\beta$-defensin 1 gene (DEFB1), encoding an anti-microbial peptide that can act against $C$. albicans [81], was associated with decreased Candida carriage in diabetic and non-diabetic patients [82]. The same SNP was associated with increased susceptibility to Candida infections in ICU surgical patients [72]. However, in the absence of replication and functional evidence, these observations will need further investigations.

Genome-wide approaches Most genetic studies so far used a candidate gene approach, in which the genes were selected for their expected role in host immune responses to the offending pathogen based on the existing literature. Investigators have recently proposed alternative approaches to account for genes that may not be selected by this traditional approach. By analyzing the transcriptional profile of human PBMCs in response to different pathogens, Smeekens et al. identified the type I IFN pathway as specific transcriptional signature for Candida infection. By performing a genetic analysis of 11 candidate genes from this pathway, they identified SNPs in four genes to be associated with candidemia, including a SNP in the signal transducer and activator of transcription 1 (STAT1), a SNP nearby the chemokine (C-C motif) ligand 8 (CCL8), a SNP in the nuclear body protein SP110 (known also as IFN-induced protein 41 ), and a SNP in the proteasome (prosome, macropain) subunit beta type 8 (PSMB8) [83]. These novel observations suggest pivotal role of type 1 IFN signaling also in anti-Candida immunity, but biologically, the plausibility of these associations needs be further elucidated. In addition, Kumar et al. by using an immunochip of 118,989 SNPs across 186 loci identify three novel polymorphisms associated with candidemia, including SNP located in CD56, SNP between late cornified envelope (LCE) protein $4 \mathrm{~A}(L C E 4 A)$ and chromosome 1 open 


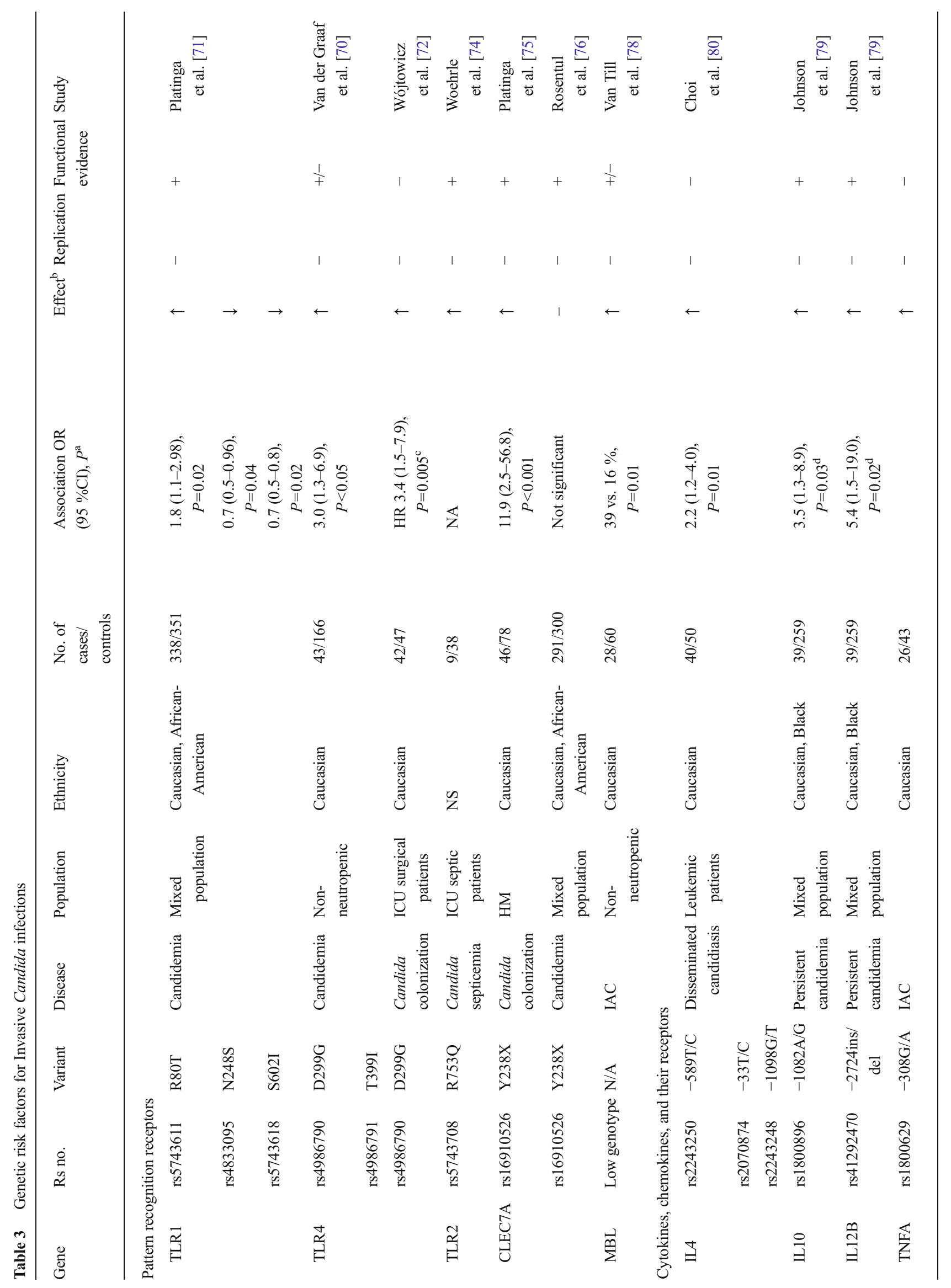




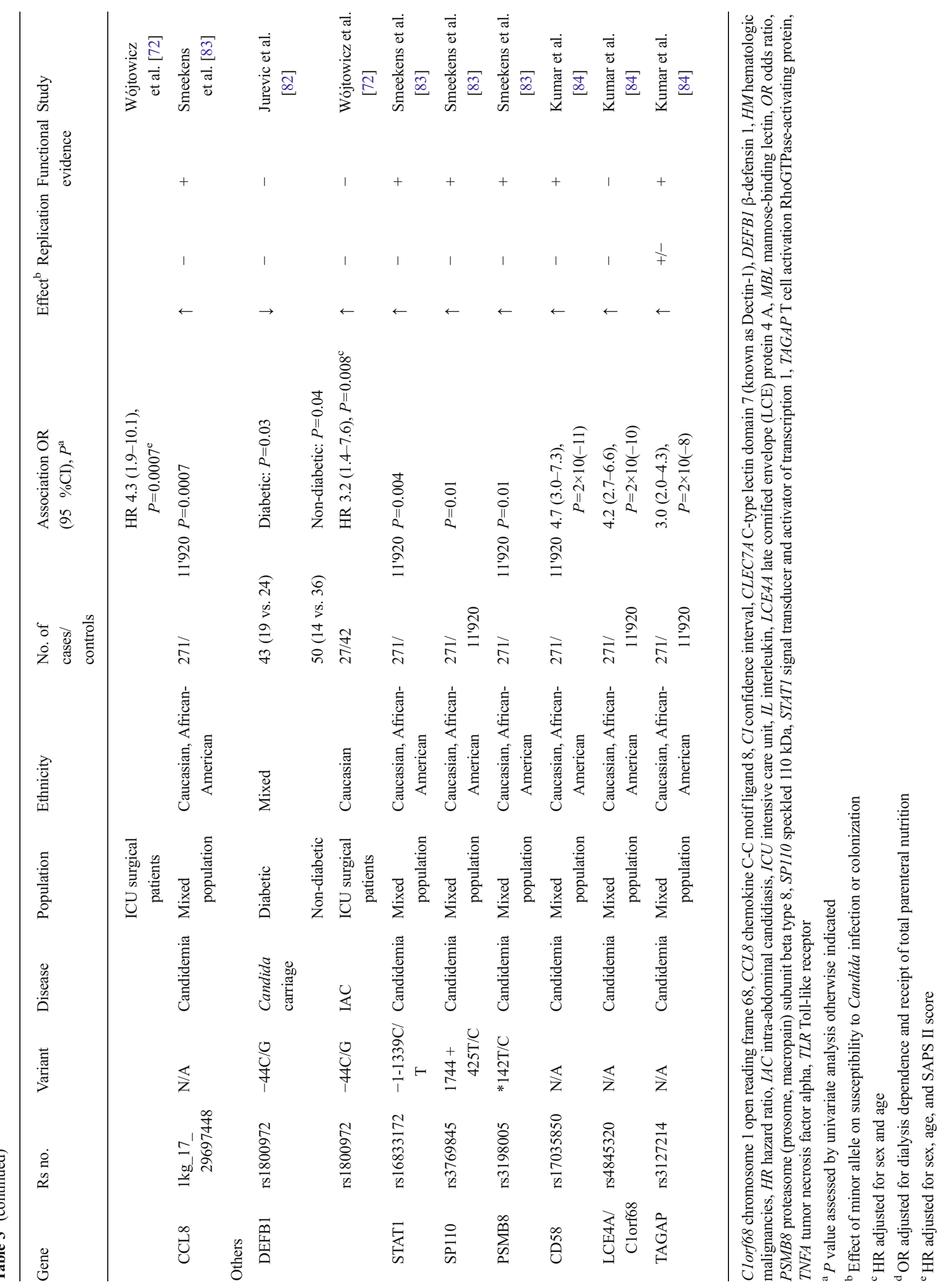


reading frame 68 (Clorf68), and SNP in T cell activation RhoGTPase-activating protein (TAGAP) [84] (Table 3).

\section{Summary, limitations, and future perspectives}

An increasing number of studies are highlighting a role for genetic polymorphisms in susceptibility to invasive fungal infections. While initial studies usually focused on one of several genes selected for their role in immune response to these pathogens (candidate gene approach), more recent work explored the role of polymorphisms at the genome-wide levels. So far, due to numerous limitations and lack of replication, existing data have not supported the use of genetic polymorphisms for individual risk stratification in the clinical practice. The studies are often limited by small sample size with insufficient power to detect associations, especially for rare variants, or flawed by lack of time-dependent analysis, adjustment for multiple testing (Bonferroni's correction), and/ or lack to account for important factors that strongly influence the endpoint. Differences between centers in the use of therapeutic and/or conditioning strategies, e.g., among patients undergoing HSCT, as well as anti-fungal prophylaxis, are another important limiting factor, impeding interpretation of the data. Moreover, some studies were prejudiced due to problematic design, inappropriate control selection for underlying disease, or use of diverse ethnicity in study population. Also, choosing the candidate gene may be subjective and was not always well defined. Aforementioned factors should be taken into account when designing new study or performing validation of existing data.

Despite these limitations, some associations are now emerging. The most consistent findings so far have been the association of polymorphisms in Dectin-1 with both invasive candidiasis as aspergillosis and the association of PTX3 polymorphisms with IA. The validity of these associations relies on the fact that they have been replicated either by the same investigators or by others, that the association is supported by functional evidence of the polymorphism affecting the gene function, and/or by the existence of mutations in the same gene/pathway leading to primary immunodeficiencies causing fungal infections. There is a clear need of well-designed prospective studies including a large number of patients with sufficient power to detect associations with selected markers, clear-cut definitions for the infectious phenotypes, and controls clearly exposed to the same risk as cases. Specific genetic polymorphism used alone or in combination with other biomarkers, together with demographic and clinical data, may be usable in the future to implement individual preventive strategies in patients at risk of fungal infection.
Acknowledgment This work was supported by the Swiss National Foundation (Grand number 324730-144054), the Leenaards Foundation, the Santos-Suarez Foundation, the Loterie Romande, Mérieux Research Grant (MRG), the FLTO Foundation (Fondation Lausannoise pour la transplantation d'organes) and the European Union's Seventh Framework Program (FP7/2007-2013) under grant agreement $n^{\circ}$ HEALTH-2010260338 (ALLFUN).

\section{References}

1. Beck-Sague C, Jarvis WR (1993) Secular trends in the epidemiology of nosocomial fungal infections in the United States, 1980 1990. National Nosocomial Infections Surveillance System. J Infect Dis 167(5):1247-1251

2. Pagano L, Caira M, Nosari A, Van Lint MT, Candoni A, Offidani M et al (2007) Fungal infections in recipients of hematopoietic stem cell transplants: results of the SEIFEM B-2004 studySorveglianza Epidemiologica Infezioni Fungine Nelle Emopatie Maligne. Clin Infect Dis 45(9):1161-1170. doi:10.1086/522189

3. Marchetti O, Bille J, Fluckiger U, Eggimann P, Ruef C, Garbino J et al (2004) Epidemiology of candidemia in Swiss tertiary care hospitals: secular trends, 1991-2000. Clin Infect Dis Off Publ Infect Dis Soc Am 38(3):311-320

4. Leroy O, Gangneux JP, Montravers P, Mira JP, Gouin F, Sollet JP et al (2009) Epidemiology, management, and risk factors for death of invasive Candida infections in critical care: a multicenter, prospective, observational study in France (2005-2006). Crit Care Med 37(5):1612-1618. doi:10.1097/CCM.0b013e31819efac0

5. Calandra TBJ, Schneider R, Mosimann F, Francioli P (1989) Clinical significance of Candida isolated from peritoneum in surgical patients. Lancet 2(8677):1437-1440

6. Eggimann P, Francioli P, Bille J, Schneider R, Wu MM, Chapuis G et al (1999) Fluconazole prophylaxis prevents intra-abdominal candidiasis in high-risk surgical patients. Crit Care Med 27(6):1066-1072

7. Prella M, Bille J, Pugnale M, Duvoisin B, Cavassini M, Calandra T et al (2005) Early diagnosis of invasive candidiasis with mannan antigenemia and antimannan antibodies. Diagn Microbiol Infect Dis 51(2):95-101. doi:10.1016/j.diagmicrobio.2004.08.015

8. Kontoyiannis DP, Marr KA, Park BJ, Alexander BD, Anaissie EJ, Walsh TJ et al (2010) Prospective surveillance for invasive fungal infections in hematopoietic stem cell transplant recipients, 20012006: overview of the Transplant-Associated Infection Surveillance Network (TRANSNET) Database. Clin Infect Dis 50(8):10911100. doi: $10.1086 / 651263$

9. Gavalda J, Len O, San Juan R, Aguado JM, Fortun J, Lumbreras C et al (2005) Risk factors for invasive aspergillosis in solid-organ transplant recipients: a case-control study. Clin Infect Dis 41(1):52 59. doi: $10.1086 / 430602$

10. Singh N, Husain S, Practice ASTIDCo (2013) Aspergillosis in solid organ transplantation. Am J Transplant Off J Am Soc Transplant Am Soc Transplant Surg 13(Suppl 4):228-241. doi:10.1111/ajt. 12115

11. Eggimann P, Bille J, Marchetti O (2011) Diagnosis of invasive candidiasis in the ICU. Ann Intensive Care 1:37. doi:10.1186/ 2110-5820-1-37

12. Maschmeyer G, Haas A, Cornely OA (2007) Invasive aspergillosis: epidemiology, diagnosis and management in immunocompromised patients. Drugs 67(11):1567-1601

13. Neofytos D, Horn D, Anaissie E, Steinbach W, Olyaei A, Fishman J et al (2009) Epidemiology and outcome of invasive fungal infection in adult hematopoietic stem cell transplant recipients: analysis of Multicenter Prospective Antifungal Therapy (PATH) Alliance registry. Clin Infect Dis 48(3):265-273. doi:10.1086/595846 
14. Palm NW, Medzhitov R (2009) Pattern recognition receptors and control of adaptive immunity. Immunol Rev 227(1):221-233

15. Romani L (2011) Immunity to fungal infections. Nat Rev Immunol 11(4):275-288. doi:10.1038/nri2939

16. Gresnigt MS, Netea MG, van de Veerdonk FL (2012) Pattern recognition receptors and their role in invasive aspergillosis. Ann N Y Acad Sci 1273:60-67. doi:10.1111/j.1749-6632.2012.06759.x

17. Netea MG, Gow NA, Munro CA, Bates S, Collins C, Ferwerda G et al (2006) Immune sensing of Candida albicans requires cooperative recognition of mannans and glucans by lectin and Toll-like receptors. J Clin Investig 116(6):1642-1650. doi:10.1172/JCI27114

18. Jouault T, Ibata-Ombetta S, Takeuchi O, Trinel PA, Sacchetti P, Lefebvre P et al (2003) Candida albicans phospholipomannan is sensed through toll-like receptors. J Infect Dis 188(1):165-172. doi: $10.1086 / 375784$

19. Steele C, Marrero L, Swain S, Harmsen AG, Zheng M, Brown GD et al (2003) Alveolar macrophage-mediated killing of Pneumocystis carinii f. sp. muris involves molecular recognition by the Dectin-1 beta-glucan receptor. J Exp Med 198(11):1677-1688

20. Brown GD, Taylor PR, Reid DM, Willment JA, Williams DL, Martinez-Pomares L et al (2002) Dectin-1 is a major beta-glucan receptor on macrophages. J Exp Med 196(3):407-412

21. Taylor PR, Tsoni SV, Willment JA, Dennehy KM, Rosas M, Findon $\mathrm{H}$ et al (2007) Dectin-1 is required for beta-glucan recognition and control of fungal infection. Nat Immunol 8(1):31-38

22. Said-Sadier N, Padilla E, Langsley G, Ojcius DM (2010) Aspergillus fumigatus stimulates the NLRP3 inflammasome through a pathway requiring ROS production and the Syk tyrosine kinase. PLoS One 5(4):e10008. doi:10.1371/journal.pone.0010008

23. Gantner BN, Simmons RM, Canavera SJ, Akira S, Underhill DM (2003) Collaborative induction of inflammatory responses by dectin-1 and Toll-like receptor 2. J Exp Med 197(9):1107-1117

24. Dennehy KM, Ferwerda G, Faro-Trindade I, Pyz E, Willment JA, Taylor PR et al (2008) Syk kinase is required for collaborative cytokine production induced through Dectin-1 and Toll-like receptors. Eur J Immunol 38(2):500-506. doi:10.1002/eji.200737741

25. Garlanda C, Hirsch E, Bozza S, Salustri A, De Acetis M, Nota R et al (2002) Non-redundant role of the long pentraxin PTX3 in antifungal innate immune response. Nature 420(6912):182-186. doi: 10.1038/nature 01195

26. Lamoth F, Rubino I, Bochud PY (2011) Immunogenetics of invasive aspergillosis. Med Mycol: Off Publ Int Soc Hum Anim Mycol 49(Suppl 1(Suppl 1)):S125-S136. doi:10.3109/13693786.2010.516408

27. Gresnigt MS, Becker KL, Smeekens SP, Jacobs CW, Joosten LA, van der Meer JW et al (2013) Aspergillus fumigatus-induced IL-22 is not restricted to a specific Th cell subset and is dependent on complement receptor 3. J Immunol 190(11):5629-5639. doi:10. 4049/jimmunol.1202601

28. Bochud PY, Bochud M, Telenti A, Calandra T (2007) Innate immunogenetics: a tool for exploring new frontiers of host defence. Lancet Infect Dis 7(8):531-542. doi:10.1016/S1473-3099(07)70185-8

29. Alcais A, Abel L, Casanova JL (2009) Human genetics of infectious diseases: between proof of principle and paradigm. J Clin Investig 119(9):2506-2514. doi:10.1172/JCI38111

30. Casanova JL, Abel L (2004) The human model: a genetic dissection of immunity to infection in natural conditions. Nat Rev 4(1):55-66

31. Dale DC, Person RE, Bolyard AA, Aprikyan AG, Bos C, Bonilla MA et al (2000) Mutations in the gene encoding neutrophil elastase in congenital and cyclic neutropenia. Blood 96(7):2317-2322

32. Klein C, Grudzien M, Appaswamy G, Germeshausen M, Sandrock I, Schaffer AA et al (2007) HAX1 deficiency causes autosomal recessive severe congenital neutropenia (Kostmann disease). Nat Genet 39(1):86-92. doi:10.1038/ng1940

33. Fischer A, Lisowska-Grospierre B, Anderson DC, Springer TA (1988) Leukocyte adhesion deficiency: molecular basis and functional consequences. Immunodefic Rev 1(1):39-54
34. Lionakis MS (2012) Genetic susceptibility to fungal infections in humans. Curr Fung Infect Rep 6(1):11-22. doi:10.1007/s12281011-0076-4

35. Lilic D (2012) Unravelling fungal immunity through primary immune deficiencies. Curr Opin Microbiol 15(4):420-426. doi:10. 1016/j.mib.2012.06.003

36. Vinh DC (2011) Insights into human antifungal immunity from primary immunodeficiencies. Lancet Infect Dis 11(10):780-792. doi:10.1016/S1473-3099(11)70217-1

37. Lanternier F, Cypowyj S, Picard C, Bustamante J, Lortholary O, Casanova JL et al (2013) Primary immunodeficiencies underlying fungal infections. Curr Opin Pediatr 25(6):736-747. doi:10.1097/ MOP.0000000000000031

38. Holland SM, DeLeo FR, Elloumi HZ, Hsu AP, Uzel G, Brodsky N et al (2007) STAT3 mutations in the hyper-IgE syndrome. N Engl J Med 357(16):1608-1619. doi:10.1056/NEJMoa073687

39. Minegishi Y, Saito M, Tsuchiya S, Tsuge I, Takada H, Hara T et al (2007) Dominant-negative mutations in the DNA-binding domain of STAT3 cause hyper-IgE syndrome. Nature 448(7157):1058 1062. doi:10.1038/nature06096

40. Camargo JF, Lobo SA, Hsu AP, Zerbe CS, Wormser GP, Holland SM (2013) MonoMAC syndrome in a patient with a GATA2 mutation: case report and review of the literature. Clin Infect Dis 57(5):697-699. doi:10.1093/cid/cit368

41. Vinh DC, Patel SY, Uzel G, Anderson VL, Freeman AF, Olivier KN et al (2010) Autosomal dominant and sporadic monocytopenia with susceptibility to mycobacteria, fungi, papillomaviruses, and myelodysplasia. Blood 115(8):1519-1529. doi:10.1182/blood2009-03-208629

42. Levy O, Bourquin JP, McQueen A, Cantor AB, Lachenauer C, Malley R (2002) Fatal disseminated Candida lusitaniae infection in an infant with chronic granulomatous disease. Pediatr Infect Dis J 21(3):262-264

43. Fleischmann J, Church JA, Lehrer RI (1986) Primary Candida meningitis and chronic granulomatous disease. Am J Med Sci 291(5):334-341

44. Ouederni M, Sanal O, Ikinciogullari A, Tezcan I, Dogu F, Sologuren I et al (2014) Clinical features of Candidiasis in patients with inherited interleukin 12 receptor beta1 deficiency. Clin Infect Dis 58(2):204-213. doi:10.1093/cid/cit722

45. Lanternier F, Pathan S, Vincent QB, Liu L, Cypowyj S, Prando C et al (2013) Deep dermatophytosis and inherited CARD9 deficiency. N Engl J Med 369(18):1704-1714. doi:10.1056/ NEJMoa1208487

46. Drewniak A, Gazendam RP, Tool AT, van Houdt M, Jansen MH, van Hamme JL et al (2013) Invasive fungal infection and impaired neutrophil killing in human CARD9 deficiency. Blood 121(13): 2385-2392. doi:10.1182/blood-2012-08-450551

47. Bochud PY, Chien JW, Marr KA, Leisenring WM, Upton A, Janer $\mathrm{M}$ et al (2008) Toll-like receptor 4 polymorphisms and aspergillosis in stem-cell transplantation. N Engl J Med 359(17):1766-1777. doi: 10.1056/NEJMoa0802629

48. Koldehoff M, Beelen DW, Elmaagacli AH (2013) Increased susceptibility for aspergillosis and post-transplant immune deficiency in patients with gene variants of TLR4 after stem cell transplantation. Transpl Infect Dis: Off J Transpl Soc 15(5):533-539. doi:10. 1111/tid.12115

49. Kesh S, Mensah NY, Peterlongo P, Jaffe D, Hsu K, Van den Brink M et al (2005) TLR1 and TLR6 polymorphisms are associated with susceptibility to invasive aspergillosis after allogeneic stem cell transplantation. Ann N Y Acad Sci 1062:95-103. doi:10.1196/ annals. 1358.012

50. Carvalho A, Cunha C, Carotti A, Aloisi T, Guarrera O, Di Ianni M et al (2009) Polymorphisms in Toll-like receptor genes and susceptibility to infections in allogeneic stem cell transplantation. Exp Hematol 37(9):1022-1029. doi:10.1016/j.exphem.2009.06.004 
51. Arbour NC, Lorenz E, Schutte BC, Zabner J, Kline JN, Jones M et al (2000) TLR4 mutations are associated with endotoxin hyporesponsiveness in humans. Nat Genet 25(2):187-191. doi:10.1038/ 76048

52. van der Graaf C, Kullberg BJ, Joosten L, Verver-Jansen T, Jacobs L, Van der Meer JW et al (2005) Functional consequences of the Asp299Gly Toll-like receptor-4 polymorphism. Cytokine 30(5): 264-268. doi:10.1016/j.cyto.2005.02.001

53. Carvalho A, De Luca A, Bozza S, Cunha C, D'Angelo C, Moretti S et al (2012) TLR3 essentially promotes protective class I-restricted memory CD8(+) T-cell responses to Aspergillus fumigatus in hematopoietic transplanted patients. Blood 119(4):967-977. doi:10. 1182/blood-2011-06-362582

54. Grube M, Loeffler J, Mezger M, Kruger B, Echtenacher B, Hoffmann P et al (2013) TLR5 stop codon polymorphism is associated with invasive aspergillosis after allogeneic stem cell transplantation. Med Mycol 51(8):818-825. doi:10.3109/13693786. 2013.809630

55. Rubino I, Coste A, Le Roy D, Roger T, Jaton K, Boeckh M et al (2012) Species-specific recognition of Aspergillus fumigatus by Toll-like receptor 1 and Toll-like receptor 6. J Infect Dis 205(6): 944-954. doi:10.1093/infdis/jir882

56. Cunha C, Di Ianni M, Bozza S, Giovannini G, Zagarella S, Zelante $\mathrm{T}$ et al (2010) Dectin-1 Y238X polymorphism associates with susceptibility to invasive aspergillosis in hematopoietic transplantation through impairment of both recipient- and donor-dependent mechanisms of antifungal immunity. Blood 116(24):5394-5402. doi:10.1182/blood-2010-04-279307

57. Chai LY, de Boer MG, van der Velden WJ, Plantinga TS, van Spriel $\mathrm{AB}$, Jacobs $\mathrm{C}$ et al (2011) The Y238X stop codon polymorphism in the human beta-glucan receptor dectin- 1 and susceptibility to invasive aspergillosis. J Infect Dis 203(5):736-743. doi:10.1093/infdis/jiq102

58. Sainz J, Lupianez CB, Segura-Catena J, Vazquez L, Rios R, Oyonarte S et al (2012) Dectin-1 and DC-SIGN polymorphisms associated with invasive pulmonary aspergillosis infection. PLoS One 7(2):e32273. doi:10.1371/journal.pone.0032273

59. Cunha C, Aversa F, Lacerda JF, Busca A, Kurzai O, Grube M et al (2014) Genetic PTX3 deficiency and aspergillosis in stem-cell transplantation. N Engl J Med 370(5):421-432. doi:10.1056/ NEJMoa1211161

60. Wójtowicz A, Lecompte T, Bibert S, Manuel O, Berger C, Boggian $\mathrm{K}$ et al (2014) PTX3 Polymorphisms are a major risk factor for invasive mold infection in solid organ transplantant recipients. ICAAC 2014 Meeting, September 2014, Washington, DC

61. Granell M, Urbano-Ispizua A, Suarez B, Rovira M, FernandezAviles F, Martinez C et al (2006) Mannan-binding lectin pathway deficiencies and invasive fungal infections following allogeneic stem cell transplantation. Exp Hematol 34(10):1435-1441. doi:10. 1016/j.exphem.2006.06.005

62. Sainz J, Hassan L, Perez E, Romero A, Moratalla A, LopezFernandez E et al (2007) Interleukin-10 promoter polymorphism as risk factor to develop invasive pulmonary aspergillosis. Immunol Lett 109(1):76-82. doi:10.1016/j.imlet.2007.01.005

63. Sainz J, Perez E, Gomez-Lopera S, Jurado M (2008) IL1 gene cluster polymorphisms and its haplotypes may predict the risk to develop invasive pulmonary aspergillosis and modulate C-reactive protein level. J Clin Immunol 28(5):473-485. doi:10.1007/s10875008-9197-0

64. Mezger M, Steffens M, Beyer M, Manger C, Eberle J, Toliat MR et al (2008) Polymorphisms in the chemokine (C-X-C motif) ligand 10 are associated with invasive aspergillosis after allogeneic stemcell transplantation and influence CXCL10 expression in monocytederived dendritic cells. Blood 111(2):534-536. doi:10.1182/blood2007-05-090928

65. Carvalho A, Cunha C, Di Ianni M, Pitzurra L, Aloisi T, Falzetti F et al (2010) Prognostic significance of genetic variants in the IL-23/
Th17 pathway for the outcome of T cell-depleted allogeneic stem cell transplantation. Bone Marrow Transplant 45(11):1645-1652. doi:10.1038/bmt.2010.28

66. Sainz J, Salas-Alvarado I, Lopez-Fernandez E, Olmedo C, Comino A, Garcia F et al (2010) TNFR1 mRNA expression level and TNFR1 gene polymorphisms are predictive markers for susceptibility to develop invasive pulmonary aspergillosis. Int $\mathrm{J}$ Immunopathol Pharmacol 23(2):423-436

67. Sainz J, Perez E, Hassan L, Moratalla A, Romero A, Collado MD et al (2007) Variable number of tandem repeats of TNF receptor type 2 promoter as genetic biomarker of susceptibility to develop invasive pulmonary aspergillosis. Hum Immunol 68(1):41-50. doi:10. 1016/j.humimm.2006.10.011

68. Cunha C, Giovannini G, Pierini A, Bell AS, Sorci G, Riuzzi F et al (2011) Genetically-determined hyperfunction of the S100B/RAGE axis is a risk factor for aspergillosis in stem cell transplant recipients. PLoS One 6(11):e27962. doi:10.1371/journal.pone.0027962

69. Zaas AK, Liao G, Chien JW, Weinberg C, Shore D, Giles SS et al (2008) Plasminogen alleles influence susceptibility to invasive aspergillosis. PLoS Genet 4(6):e1000101. doi:10.1371/journal.pgen. 1000101

70. Van der Graaf CA, Netea MG, Morre SA, Den Heijer M, Verweij PE, Van der Meer JW, Kullberg BJ (2006) Toll-like receptor 4 Asp299Gly/Thr399Ile polymorphisms are a risk factor for Candida bloodstream infection. Eur Cytokine Netw 17:29-34

71. Plantinga TSJM, Scott WK, van de Vosse E, Velez Edwards DR, Smith PB, Alexander BD, Yang JC, Kremer D, Laird GM, Oosting M, Joosten LA, van der Meer JW, van Dissel JT, Walsh TJ, Perfect JR, Kullberg BJ, Netea MG (2012) Toll-like receptor 1 polymorphisms increase susceptibility to candidemia. J Infect Dis 205(6):934-943

72. Wojtowicz A, Tissot F, Lamoth F, Orasch C, Eggimann P, Siegemund M et al (2014) Polymorphisms in tumor necrosis factor-alpha increase susceptibility to intra-abdominal Candida infection in high-risk surgical ICU patients*. Crit Care Med 42(4): e304-e308. doi:10.1097/CCM.0000000000000208

73. Netea MG, Van Der Graaf CA, Vonk AG, Verschueren I, Van Der Meer JW, Kullberg BJ (2002) The role of toll-like receptor (TLR) 2 and TLR4 in the host defense against disseminated candidiasis. J Infect Dis 185(10):1483-1489. doi:10.1086/340511

74. Woehrle T, Du W, Goetz A, Hsu HY, Joos TO, Weiss M et al (2008) Pathogen specific cytokine release reveals an effect of TLR2 Arg753Gln during Candida sepsis in humans. Cytokine 41(3): 322-329. doi:10.1016/j.cyto.2007.12.006

75. Plantinga TS, van der Velden WJ, Ferwerda B, van Spriel AB, Adema G, Feuth T et al (2009) Early stop polymorphism in human DECTIN-1 is associated with increased Candida colonization in hematopoietic stem cell transplant recipients. Clin Infect Dis 49(5):724-732

76. Rosentul DC, Plantinga TS, Oosting M, Scott WK, Velez Edwards DR, Smith PB et al (2011) Genetic variation in the dectin-1/CARD9 recognition pathway and susceptibility to candidemia. J Infect Dis 204(7):1138-1145. doi:10.1093/infdis/jir458

77. Saijo S, Fujikado N, Furuta T, Chung SH, Kotaki H, Seki K et al (2007) Dectin-1 is required for host defense against Pneumocystis carinii but not against Candida albicans. Nat Immunol 8(1):39-46. doi:10.1038/ni1425

78. van Till WMP, de Boer M, Hart MH, Beld MG, Boermeester MA (2008) Mannose-binding lectin deficiency facilitates abdominal Candida infections in patients with secondary peritonitis. Clin Vaccine Immunol 15:65-70

79. Johnson MD, Plantinga TS, van de Vosse E, Velez Edwards DR, Smith PB, Alexander BD et al (2012) Cytokine gene polymorphisms and the outcome of invasive candidiasis: a prospective cohort study. Clin Infect Dis Off Publ Infect Dis Soc Am 54(4): 502-510. doi:10.1093/cid/cir827

80. Choi EH, Foster CB, Taylor JG, Erichsen HC, Chen RA, Walsh TJ et al (2003) Association between chronic 
disseminated candidiasis in adult acute leukemia and common IL4 promoter haplotypes. J Infect Dis 187(7):11531156. doi:10.1086/368345

81. Schroeder BO, Wu Z, Nuding S, Groscurth S, Marcinowski M, Beisner J et al (2011) Reduction of disulphide bonds unmasks potent antimicrobial activity of human beta-defensin 1. Nature 469(7330):419-423. doi:10.1038/nature09674

82. Jurevic RJ, Bai M, Chadwick RB, White TC, Dale BA (2003) Singlenucleotide polymorphisms (SNPs) in human beta-defensin 1: highthroughput SNP assays and association with Candida carriage in type I diabetics and nondiabetic controls. J Clin Microbiol 41(1):90-96

83. Smeekens SP, Ng A, Kumar V, Johnson MD, Plantinga TS, van Diemen C et al (2013) Functional genomics identifies type I interferon pathway as central for host defense against Candida albicans. Nat Commun 4:1342. doi:10.1038/ncomms2343

84. Kumar V, Cheng SC, Johnson MD, Smeekens SP, Wojtowicz A, Giamarellos-Bourboulis E et al (2014) Immunochip SNP array identifies novel genetic variants conferring susceptibility to candidaemia. Nat Commun 5:4675. doi:10.1038/ncomms5675

85. Glocker EO, Hennigs A, Nabavi M, Schaffer AA, Woellner C, Salzer $\mathrm{U}$ et al (2009) A homozygous CARD9 mutation in a family with susceptibility to fungal infections. N Engl J Med 361(18):1727-1735

86. Zhang Q, Davis JC, Lamborn IT, Freeman AF, Jing H, Favreau AJ et al (2009) Combined immunodeficiency associated with DOCK8 mutations. N Engl J Med 361(21):2046-2055. doi:10.1056/ NEJMoa0905506

87. Picard C, Casanova JL, Puel A (2011) Infectious diseases in patients with IRAK-4, MyD88, NEMO, or IkappaBalpha deficiency. Clin Microbiol Rev 24(3):490-497. doi:10.1128/CMR. 00001-11

88. Schimke LF, Rieber N, Rylaarsdam S, Cabral-Marques O, Hubbard N, Puel A et al (2013) A novel gain-of-function IKBA mutation underlies ectodermal dysplasia with immunodeficiency and polyendocrinopathy. J Clin Immunol 33(6):1088-1099. doi:10. 1007/s10875-013-9906-1

89. Morgan NV, Goddard S, Cardno TS, McDonald D, Rahman F, Barge D et al (2011) Mutation in the TCRalpha subunit constant gene (TRAC) leads to a human immunodeficiency disorder characterized by a lack of TCRalphabeta+ T cells. J Clin Investig 121(2): 695-702. doi:10.1172/JCI41931

90. Feske S, Gwack Y, Prakriya M, Srikanth S, Puppel SH, Tanasa B et al (2006) A mutation in Orail causes immune deficiency by abrogating CRAC channel function. Nature 441(7090):179-185. doi:10.1038/nature04702

91. Abdollahpour H, Appaswamy G, Kotlarz D, Diestelhorst J, Beier R, Schaffer AA et al (2012) The phenotype of human STK4 deficiency. Blood 119(15):3450-3457. doi:10.1182/blood-2011-09-378158

92. Nehme NT, Pachlopnik Schmid J, Debeurme F, Andre-Schmutz I, Lim A, Nitschke P et al (2012) MST1 mutations in autosomal recessive primary immunodeficiency characterized by defective naive T-cell survival. Blood 119(15):3458-3468. doi:10.1182/ blood-2011-09-378364

93. Caudy AA, Reddy ST, Chatila T, Atkinson JP, Verbsky JW (2007) CD25 deficiency causes an immune dysregulation, polyendocrinopathy, enteropathy, X-linked-like syndrome, and defective IL-10 expression from CD4 lymphocytes. J Allergy Clin Immunol 119(2):482-487. doi:10.1016/j.jaci.2006.10.007

94. Ouederni M, Vincent QB, Frange P, Touzot F, Scerra S, Bejaoui M et al (2011) Major histocompatibility complex class II expression deficiency caused by a RFXANK founder mutation: a survey of 35 patients. Blood 118(19):5108-5118. doi:10.1182/blood-2011-05-352716

95. Gorska MM, Alam R (2012) A mutation in the human Uncoordinated 119 gene impairs TCR signaling and is associated with CD4 lymphopenia. Blood 119(6):1399-1406. doi:10.1182/ blood-2011-04-350686

96. Li FY, Chaigne-Delalande B, Kanellopoulou C, Davis JC, Matthews HF, Douek DC et al (2011) Second messenger role for
$\mathrm{Mg} 2+$ revealed by human T-cell immunodeficiency. Nature 475(7357):471-476. doi:10.1038/nature 10246

97. Kuijpers TW, Ijspeert H, van Leeuwen EM, Jansen MH, Hazenberg $\mathrm{MD}$, Weijer KC et al (2011) Idiopathic CD4+ T lymphopenia without autoimmunity or granulomatous disease in the slipstream of RAG mutations. Blood 117(22):5892-5896. doi:10.1182/blood2011-01-329052

98. Puck JM (2011) Neonatal screening for severe combined immunodeficiency. Curr Opin Pediatr 23(6):667-673. doi:10.1097/MOP. 0b013e32834cb9b0

99. Chandesris MO, Melki I, Natividad A, Puel A, Fieschi C, Yun L et al (2012) Autosomal dominant STAT3 deficiency and hyper-IgE syndrome: molecular, cellular, and clinical features from a French national survey. Medicine 91(4):e1-e19. doi:10.1097/MD. 0b013e31825f95b9

100. Woellner C, Gertz EM, Schaffer AA, Lagos M, Perro M, Glocker EO et al (2010) Mutations in STAT3 and diagnostic guidelines for hyper-IgE syndrome. J Allergy Clin Immunol 125(2):424-32 e8. doi:10.1016/j.jaci.2009.10.059

101. Engelhardt KR, McGhee S, Winkler S, Sassi A, Woellner C, LopezHerrera $\mathrm{G}$ et al (2009) Large deletions and point mutations involving the dedicator of cytokinesis 8 (DOCK8) in the autosomalrecessive form of hyper-IgE syndrome. $\mathrm{J}$ Allergy Clin Immunol 124(6):1289-302 e4. doi:10.1016/j.jaci.2009.10.038

102. Kisand K, Boe Wolff AS, Podkrajsek KT, Tserel L, Link M, Kisand $\mathrm{KV}$ et al (2010) Chronic mucocutaneous candidiasis in APECED or thymoma patients correlates with autoimmunity to Th17-associated cytokines. J Exp Med 207(2):299-308. doi:10.1084/jem.20091669

103. Sarkadi AK, Tasko S, Csorba G, Toth B, Erdos M, Marodi L (2014) Autoantibodies to IL-17A may be correlated with the severity of mucocutaneous candidiasis in APECED patients. J Clin Immunol 34(2):181-193. doi:10.1007/s10875-014-9987-5

104. Minegishi Y, Saito M, Morio T, Watanabe K, Agematsu K, Tsuchiya $S$ et al (2006) Human tyrosine kinase 2 deficiency reveals its requisite roles in multiple cytokine signals involved in innate and acquired immunity. Immunity 25(5):745-755. doi:10.1016/j. immuni.2006.09.009

105. de Beaucoudrey L, Puel A, Filipe-Santos O, Cobat A, Ghandil P, Chrabieh $\mathrm{M}$ et al (2008) Mutations in STAT3 and IL12RB1 impair the development of human IL-17-producing T cells. J Exp Med 205(7):1543-1550. doi:10.1084/jem.20080321

106. Prando C, Samarina A, Bustamante J, Boisson-Dupuis S, Cobat A, Picard C et al (2013) Inherited IL-12p40 deficiency: genetic, immunologic, and clinical features of 49 patients from 30 kindreds. Medicine 92(2):109-122. doi:10.1097/MD.0b013e31828a01f9

107. Puel A, Cypowyj S, Bustamante J, Wright JF, Liu L, Lim HK et al (2011) Chronic mucocutaneous candidiasis in humans with inborn errors of interleukin-17 immunity. Science 332(6025):65-68. doi: 10.1126/science. 1200439

108. Liu L, Okada S, Kong XF, Kreins AY, Cypowyj S, Abhyankar A et al (2011) Gain-of-function human STAT1 mutations impair IL-17 immunity and underlie chronic mucocutaneous candidiasis. J Exp Med 208(8):1635-1648. doi:10.1084/jem.20110958

109. van de Veerdonk FL, Plantinga TS, Hoischen A, Smeekens SP, Joosten LA, Gilissen C et al (2011) STAT1 mutations in autosomal dominant chronic mucocutaneous candidiasis. N Engl J Med 365(1):54-61. doi:10.1056/NEJMoa1100102

110. Boisson B, Wang C, Pedergnana V, Wu L, Cypowyj S, Rybojad M et al (2013) An ACT1 mutation selectively abolishes interleukin-17 responses in humans with chronic mucocutaneous candidiasis. Immunity 39(4):676-686. doi:10.1016/j.immuni.2013.09.002

111. Seo KW, Kim DH, Sohn SK, Lee NY, Chang HH, Kim SW et al (2005) Protective role of interleukin-10 promoter gene polymorphism in the pathogenesis of invasive pulmonary aspergillosis after allogeneic stem cell transplantation. Bone Marrow Transplant 36(12):1089-1095. doi:10.1038/sj.bmt.1705181 